\title{
Chlorination and Mussel Control in the Cooling Conduits of a Tropical Coastal Power Station
}

\author{
S. Rajagopal, ${ }^{* a}$ K. V. K. Nair, ${ }^{b}$ J. Azariah,${ }^{a}$ G. van der Velde ${ }^{c}$ \\ $\&$ H. A. Jenner ${ }^{d}$ \\ ${ }^{a}$ Department of Zoology, University of Madras, Guindy Campus, Madras 600 025, India \\ ${ }^{b}$ Water and Steam Chemistry Laboratory, Indira Gandhi Centre for Atomic Research Campus, \\ Kalpakkam 603 102, India \\ ${ }^{c}$ Laboratory of Aquatic Ecology, Department of Ecology, Faculty of Science, University of Nijmegen, \\ Toernooiveld, 6525 ED, Nijmegen, The Netherlands \\ ${ }^{d}$ KEMA Environmental Services, PO Box 9035, 6800 ET, Arnhem, The Netherlands \\ (Received 8 December 1994; revised version received 23 May 1995; \\ accepted I June 1995)

\begin{abstract}
$A B S T R A C T$ the cooling conduits of Madras Atomic Power Station (Kalpakkam), in spite of intermittent chlorination used as a fouling control measure. A diver-assisted inspection of the tunnel proved that the green mussel. Perna viridis (L.) was the major component of the fouling community inside the cooling conduits. Maximum biomass value recorded was $211 \mathrm{~kg} / \mathrm{m}^{2}$, observed inside the forebay shaft at a depth of $22.5 \mathrm{~m}$. The total biomass of fouling in the entire tunnel system was estimated to be 578 tonnes, of which the contribution by P.viridis alone was 411 tonnes. High-level chlorination, followed by continuous low-level chlorination brought large quantities of sessile biomass from the tunnel to travelling water screens (TWS). A total biomass of about 187 tonnes of fouling debris was collected from TWS during February 1988 to January 1990. Of these, P.viridis accounted for 164 tonnes. The sizefrequency distribution of P.viridis collected on the TWS clearly showed that the pattern of green mussels in the adjacent coastal waters. The present study showed that intermittent chlorination is an ineffective method for mussel control in the power station cooling conduits. Continuous high-level chlorination is useful for dislodging established mussel communities from intake tunnels.
\end{abstract} \\ The rationale for the present study has been the continued problem of biofouling in \\ appearance of young mussels (0-2 cm shell length) was correlated with the breeding
}

*Present address: Laboratory of Aquatic Ecology, Department of Ecology, Faculty of Science, University of Nijmegen, Toernooiveld, 6525 ED, Nijmegen, The Netherlands. 


\section{INTRODUCTION}

Most nuclear power stations are strategically placed in close proximity to the sea, with a view to making use of the cheap and abundant source of seawater as a heat sink. Settlement and growth of fouling organisms in the cooling systems of these stations often constitutes a problem of considerable economic significance (Jenner, 1980; Brankevich et al., 1988). Four categories of biofouling-induced problems in power stations can be distinguished: blockage of free flow of water in the cooling conduits and consequent mechanical damage to pumps (Neitzel et al. 1984), clogging of condenser tubes (Henager et al., 1985), reduction in heat transfer efficiency (Rajagopal et al., 1994a) and acceleration of corrosion (Fischer et al., 1984). Apart from this, fouling in nuclear power stations has the potential to affect raw water systems including back-up cooling loops provided for safety-related cooling systems (Neitzel et al., 1986). Although the problems outlined above are likely to be encountered in any power station using seawater as a coolant to a greater or lesser extent, comprehensive studies in this area are surprisingly very few (Graham et al., 1975; Jenner, 1982; Lewis, 1985; Rajagopal, 1991).

Madras Atomic Power Station (MAPS) is situated $65 \mathrm{~km}$ south of Madras on the east coast of India. MAPS experienced severe pressure drop beyond the station's operational design limit in the forebay (Nair, 1990), and flow blockage (by mussel shells) in the condenser tubes due to heavy growth of calcareous fouling organisms in the cooling systems (Rajagopal et al., 1991a). The station operators, prompted by such fouling-induced flowreduction, conducted diving inspections of the seawater intake tunnel with the help of a Remotely Operated Vehicle (ROV). The samples collected by divers and ROV photographs showed extensive growth of fouling organisms, dominated by green mussel, Perna viridis (L.) in the sub-seabed tunnel. After tunnel inspection, MAPS switched over to highlevel chlorination in January 1988 to dislodge the excessive growth of mussels, followed by continuous low-level chlorination to control recolonization and maintain satisfactory flow of cooling water.

The present paper focuses on the problem of flow-reduction due to biofouling, the relative biomass and composition of different fouling organisms at various depths from the divers' collected samples, the chlorination schedule used to remove excessive biofouling growth and data on the subsequent removal rate of different foulants from MAPS intake tunnel. Attempts have also been made to confirm the relationship between removal of fouling debris and seawater volume transport in the cooling conduits of MAPS.

\section{MATERIALS AND METHODS}

\section{Site description}

Madras Atomic Power Station (MAPS) consists of two units, each with an installed capacity of $235 \mathrm{Mw}(\mathrm{e})$, and is situated at Kalpakkam $\left(12^{\circ} 33^{\prime} \mathrm{N}\right.$ and $\left.80^{\circ} 11^{\prime} \mathrm{E}\right)$ on the east coast of India. The cooling water requirement for the two units operating at full power is about $35 \mathrm{~m}^{3} / \mathrm{sec}$. The seawater cooling system consists of an intake structure, located $420 \mathrm{~m}$ away from the shore in the sea (Fig. 1). A tunnel, $468 \mathrm{~m}$ long and $53 \mathrm{~m}$ below mean sea level (MSL), connects the forebay and the pump house to an intake structure. At the forebay, 12 pumps ( 6 for each unit) draw seawater and circulate it through the condensers 


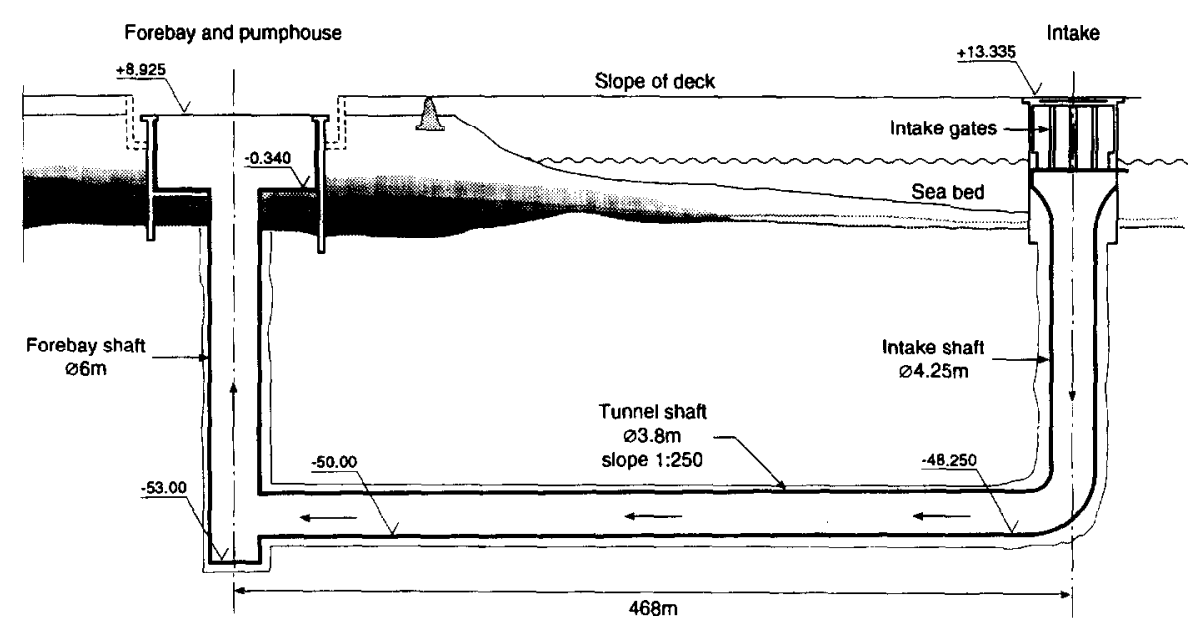

Fig. 1. Schematic diagram of submarine tunnel of Madras Atomic Power Station (not drawn to scale; + and - signs indicate levels above and below the mean sea level).

and other heat exchangers. The coolant seawater velocity when all the 12 pumps are running, works out to be about $3.5 \mathrm{~m} / \mathrm{sec}$ in the horizontal section of the tunnel (Madras Atomic Power Station Design Manual, 1975). In the forebay, travelling water screens (TWS) with $1 \mathrm{~cm} \times 1 \mathrm{~cm}$ mesh are used to remove smaller objects before water is pumped to the condensers. For further details of the cooling circuit, refer to Rajagopal et al. (1991a). MAPS unit I was commissioned in July 1983; chlorination based on an intermittent schedule ( 1 to $2 \mathrm{mg}$ /litre residual at outfall for $1 \mathrm{~h}$, once in $8 \mathrm{~h}$ ) has been in use in the cooling water system as a biofouling control measure since 1979 .

The present chlorination practice at MAPS is to bring bulk liquified chlorine in 1 tonne cylinders and inject it by feeding through a vaporiser. The gaseous chlorine from the vaporiser passes through a vacuum regulator. The chlorine injectors suck the chlorine into the down stream of the vacuum injectors. Chlorine is injected into the seawater at the intake point.

\section{Hydrographic conditions}

Collection of surface water samples was done at fortnightly intervals. The temperature was measured by a thermometer of $0.1^{\circ} \mathrm{C}$ accuracy. Salinity was estimated by the silver nitrate method (Strickland \& Parsons, 1972). Dissolved oxygen content was measured by Winkler's method and seston by using Millipore filter paper of $0.45 \mu \mathrm{m}$ porosity (Strickland \& Parsons, 1972). For pH measurement, a digital pH meter (model Kent EIL 3055) was used. Dissolved nutrients (nitrite, nitrate, inorganic phosphate and reactive silicate) and chlorophyll- $a$ analyses were carried out following procedures outlined by Parsons et al. (1984).

\section{Head loss}

Fouling-induced water blockage in the conduit was assessed by determining the water level differences between forebay and intake (head loss). This measurement was done from the platform at the respective places, using a lead and line (Rajagopal et al., 1991b). 
Variations in the water level differences are also influenced by the number of pumps operating. With a view to maintaining uniformity, measurements were made only when 11 pumps were operating. A total of 40 measurements were made during 4 March 1986 to 12 March 1990.

\section{Diving inspections}

The intake system was inspected using an ROV from 9 to 16 December 1987. Apart from this, a team of divers was employed to collect samples from various parts of the submarine tunnel system. A total number of 19 quadrats $\left(225 \mathrm{~cm}^{2}\right.$ each) were sampled. The samples collected by divers were sorted out to species level and biomass (wet weight) of individual species determined. Based on these data, total biomass of different fouling organisms inside the tunnel was calculated (Rajagopal et al., 1991a).

\section{Chlorine doses}

After inspection of the tunnel by divers. continuous chlorination of cooling water was started in January 1988. In the initial two months relatively higher doses (shock-doses) were given. Based on the quantity of chlorine added and the volume of water flowing through the tunnel, dose levels were calculated. In addition, actual measurements of total residual chlorine levels in the forebay well were also made using orthotolidine method (White, 1972). Results of biweekly measurements were averaged to obtain mean monthly figures during the period January 1988 to January 1990.

\section{Fouling debris removal from the tunnel}

Subsequent to high-level chlorination, fouling debris started coming out of the tunnel along with flowing water. This was collected on the TWS at the forebay. The collected fouling organisms from TWS were transferred to drums (45 or 200 litre capacity). Each day, total number of drums were noted and randomly a few drums were selected for studying the fouling composition. Fouling organisms were sorted out up to species level and later weighed (wet weight) and counted separately for their individual biomass and numerical abundance. Size-frequency distribution of the most dominant species, P.viridis, was also determined using random samples. Afterwards, the green mussel shells were sorted out into two categories, i.e. live and dead (based on whether the shells were closed or agape) and weighed separately.

\section{Growth rate}

Green mussels growing on the experimental teakwood panels $(150 \times 100 \times 5 \mathrm{~mm})$ suspended in the adjacent coastal waters were collected at monthly intervals and the shell lengths measured to determine their growth rate (Page \& Hubbard, 1987).

\section{RESULTS}

\section{Hydrographic conditions}

Table 1 summarises the data on hydrographical parameters during the study period. 


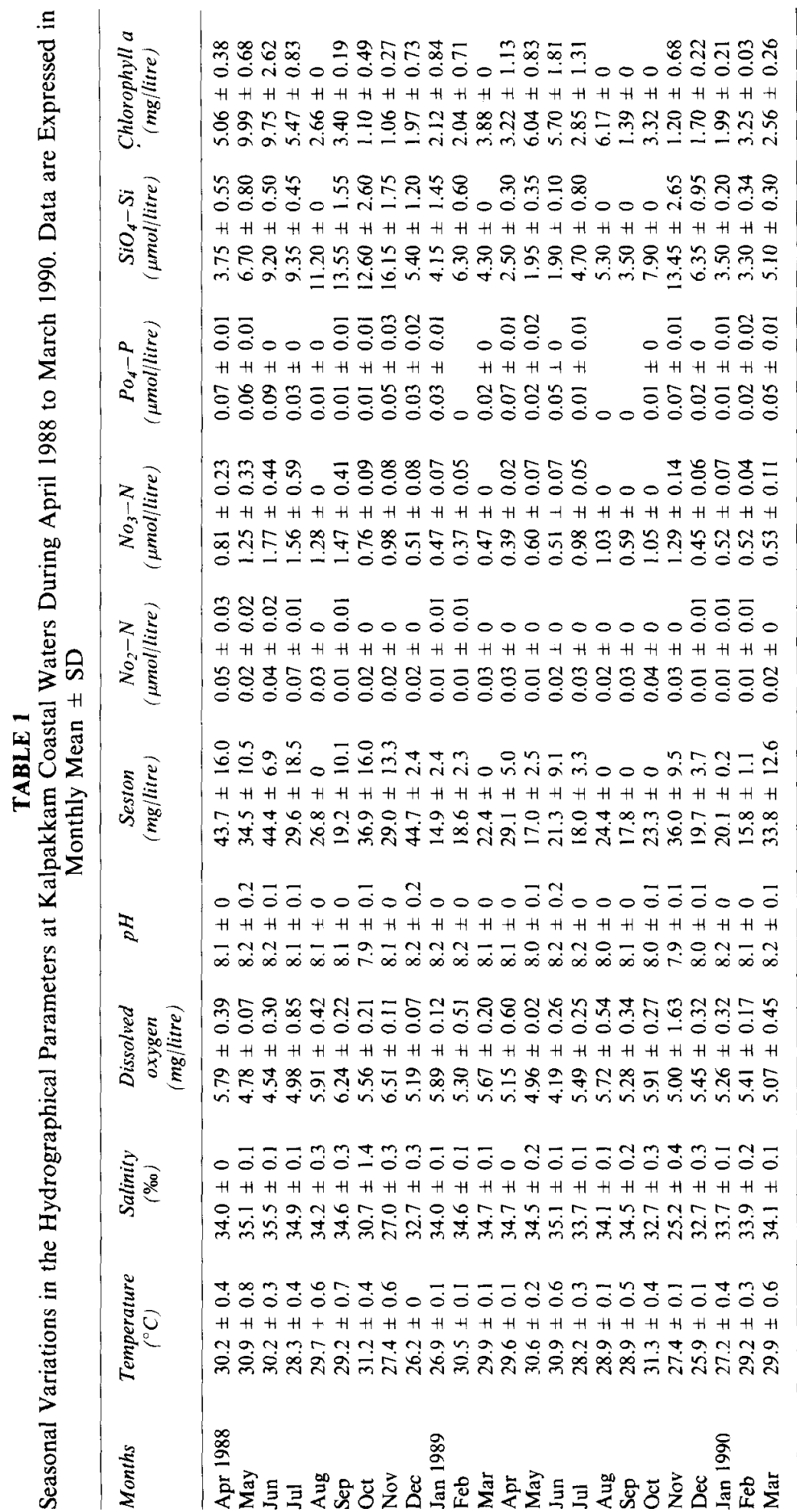




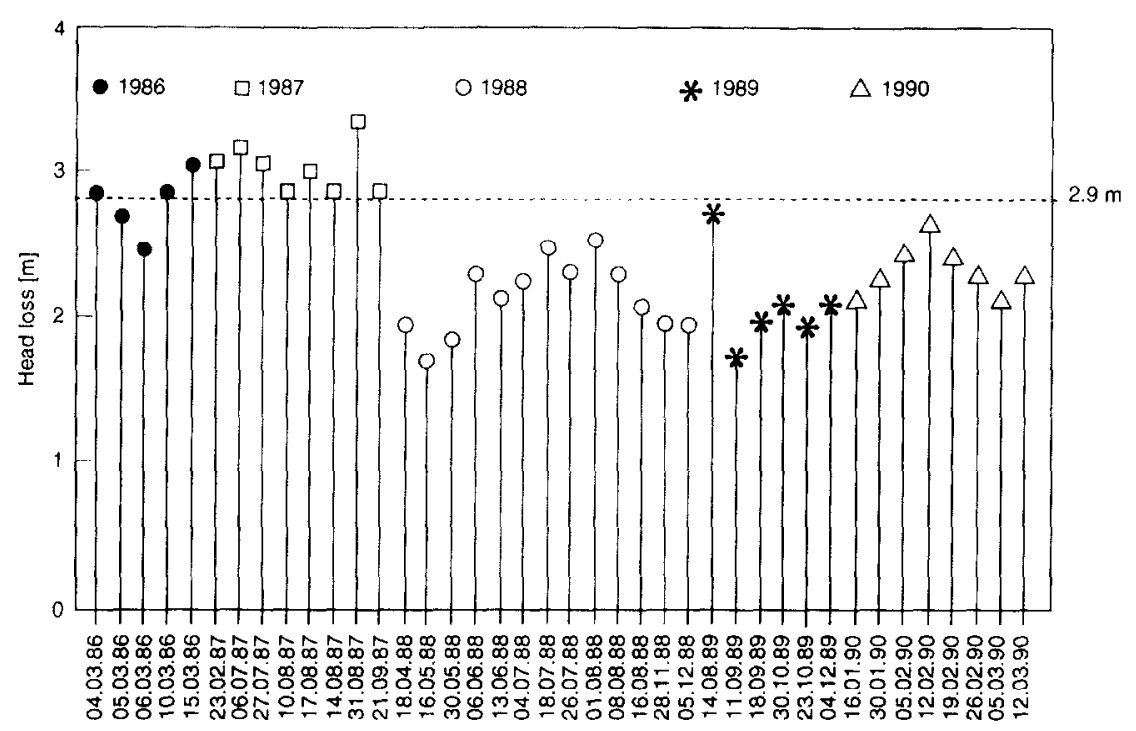

Fig. 2. Variations in head loss at the MAPS forebay during 1986 1990 when 11 pumps were operational (dotted line represents design limit).

\section{Head loss}

Head loss caused by fouling-induced flow blockage inside the tunnel showed a gradual increase from 1986 to 1987 (Fig. 2). The maximum head loss recorded was $3.44 \mathrm{~m}$ on 31 August 1987 and sudden decrease was observed on 18 April 1988. The head loss readings remained within $2.70 \mathrm{~m}$ from 30 May 1988 to 12 March 1990.

\section{Diving inspections}

Biomass values of fouling debris collected by divers from inside the tunnel system show a maximum value of $211 \mathrm{~kg} / \mathrm{m}^{2}$ inside the forebay shaft at a depth of $22.5 \mathrm{~m}$ (Table 2). The minimum value observed was $35 \mathrm{~kg} / \mathrm{m}^{2}$ at a depth of $5 \mathrm{~m}$ in the forebay shaft. The average biomass values for the intake and forebay shaft were 70 and $105 \mathrm{~kg} / \mathrm{m}^{2}$, respectively. Two samples collected from the horizontal conduit gave an average biomass value of $66 \mathrm{~kg} / \mathrm{m}^{2}$. The total biomass of fouling debris in the entire tunnel system was also estimated based on the biomass levels in different sections. This was found to be 578 tonnes (wet weight), of which the contribution of green mussel alone was 411 tonnes (Rajagopal et al., 1991 a).

\section{Volume transport}

The volume of scawater transported through the intake tunnel during the period January 1988 to January 1990 (Table 3), ranged from $5.16 \times 10^{5} \mathrm{~m}^{3} /$ day (January 1988) to $3.66 \times$ $10^{6} \mathrm{~m}^{3} /$ day (July 1988). Lower values during January to February 1988 and January to June 1989, indicate shut-down periods of the plant when only a limited number of pumps were operated. 
TABLE 2

Fouling Biomass Collected by Divers at the 19 Sampling Points from the Cooling Conduits of Madras Atomic Power Station

\begin{tabular}{lccc}
\hline Depth $(\mathrm{m})$ & \multicolumn{3}{c}{ Fouling biomass $\left(\mathrm{kg} / \mathrm{m}^{2}\right)$} \\
\cline { 2 - 4 } & Perna viridis & Other fouling species & Total biomass \\
\hline Intake -3 & 29.76 & 9.24 & 39.0 \\
Intake -3 & 35.76 & 5.44 & 41.2 \\
Intake -9 & 28.40 & 7.60 & 36.0 \\
Intake -18 & 109.00 & 20.30 & 129.3 \\
Intake -18 & 88.62 & 17.38 & 106.0 \\
Forebay -5 & 10.21 & 24.39 & 34.6 \\
Forebay -6 & 51.71 & 23.89 & 75.6 \\
Forebay -6 & 101.32 & 40.98 & 142.3 \\
Forebay -7.5 & 37.02 & 10.08 & 47.1 \\
Forebay -12 & 136.31 & 25.19 & 161.5 \\
Forebay -22.5 & 184.92 & 26.18 & 211.1 \\
Forebay -36 & 110.12 & 22.08 & 132.2 \\
Forebay -48 & 75.11 & 23.59 & 98.7 \\
Forebay -48 & 92.17 & 8.23 & 100.4 \\
Forebay -49 & 14.05 & 27.65 & 41.7 \\
Forebay -50 & 81.81 & 21.49 & 103.3 \\
Forebay -53 & 94.71 & 15.29 & 110.0 \\
Inside tunnel $-8 \mathrm{~m}(49 \mathrm{~m})$ & 33.99 & 24.91 & 58.9 \\
Inside tunnel $-8 \mathrm{~m}(53 \mathrm{~m})$ & 53.44 & 19.36 & 72.8 \\
\hline
\end{tabular}

\section{Chlorine doses}

Monthly averages of chlorine added (calculated value) and residual chlorine levels recorded in the forebay are given in Table 3 . The difference between these two data gives a measure of the chlorine demand of the cooling water. Higher doses were administered in the months January and February 1988 which gave a total residual of $1.4 \mathrm{mg} /$ litre or more at the forebay. From May 1988 onwards continuous low-level chlorination was resorted to, in order to give a residual level of $0.2 \mathrm{mg} /$ litre or less, and this was maintained for the rest of the period. However, during the months of May and June 1989, slightly higher doses (average $1.6 \mathrm{mg} /$ litre) were used.

\section{Fouling debris removal from the tunnel}

Quantitative data on fouling debris collected on TWS shows a higher rate of removal during the three month period following high-level chlorination (Fig. 3). A maximum of 45.4 tonnes was collected in February 1988. During the period of study, total number of taxa collected on the TWS was found to be 98, of which 61 were Mollusca (Table 4). However, TWS collection was mostly dominated by the green mussel, P.viridis, as expected. Monthly variations in relative abundance of green mussels also clearly indicated its dominance over the other species on the TWS collection (Fig. 4). A total biomass of about 187 tonnes of fouling debris was collected from TWS during February 1988 to 
TABLE 3

Seawater Volume Transport, Injected Chlorine Dose and Measured Levels of Residual Chlorine in the Forebay During January 1988 to January 1990 (Monthly Mean \pm SD)

\begin{tabular}{lccc} 
Months & $\begin{array}{c}\text { Injected } \\
\text { (hlorine dose } \\
\text { (mg/itre) }\end{array}$ & $\begin{array}{c}\text { Residual } \\
\text { (hlorine at forehay } \\
\text { (mg/litre) }\end{array}$ & $\begin{array}{c}\text { Seawater } \\
\text { volume transport } \\
\left.\left(m^{3} \text { day }\right) \times 1\right)^{3}\end{array}$ \\
*Jan 1988 & $3.37 \pm 0.92$ & $2.09 \pm 0.63$ & 516.4 \\
${ }^{*}$ Feb & $2.55 \pm 0.67$ & $1.38 \pm 0.40$ & 1651.4 \\
${ }^{*}$ Mar & $1.11 \pm 0.28$ & $0.51 \pm 0.19$ & 2567.7 \\
Apr & $0.85 \pm 0.30$ & $0.32 \pm 0.18$ & 3353.7 \\
May & $0.40 \pm 0.11$ & $0.17 \pm 0.05$ & 3382.4 \\
Jun & $0.26 \pm 0.09$ & $0.09 \pm 0.01$ & 3480.3 \\
Jul & $0.24 \pm 0.10$ & $0.05 \pm 0.01$ & 3661.5 \\
Aug & $0.29 \pm 0.14$ & $0.00 \pm 0.08$ & 3295.9 \\
Sept & $0.34 \pm 0.08$ & $0.13 \pm 0.03$ & 2298.5 \\
Oct & $0.43 \pm 0.17$ & $0.18 \pm 0.10$ & 2094.2 \\
Nov & $0.36 \pm 0.11$ & $0.16 \pm 0.05$ & 2547.7 \\
Dec & $0.43 \pm 0.22$ & $0.21 \pm 0.07$ & 2496.1 \\
Jan 1989 & $0.95 \pm 0.39$ & $0.38 \pm 0.21$ & 1446.7 \\
Feb & $0.71 \pm 0.45$ & $0.30 \pm 0.19$ & 1414.6 \\
Mar & $0.61 \pm 0.34$ & $0.24 \pm 0.15$ & 1252.6 \\
Apr & $0.78 \pm 0.30$ & $0.43 \pm 0.23$ & 841.9 \\
May & $1.57 \pm 0.79$ & $0.63 \pm 0.37$ & 1049.7 \\
Jun & $1.69 \pm 1.03$ & $0.84 \pm 0.69$ & 1038.7 \\
Jul & $0.23 \pm 0.18$ & $0.06 \pm 0.01$ & 3369.6 \\
Aug & $0.65 \pm 0.27$ & $0.29 \pm 0.12$ & 3407.8 \\
Sept & $0.23 \pm 0.09$ & $0.02 \pm 0.01$ & 3483.3 \\
Oct & $0.36 \pm 0.15$ & $0.16 \pm 0.04$ & 3298.3 \\
Nov & $0.42 \pm 0.29$ & $0.22 \pm 0.08$ & 3184.3 \\
Dec & $0.37 \pm 0.18$ & $0.13 \pm 0.07$ & 3145.3 \\
Jan 1990 & $0.27 \pm 0.07$ & $0.08 \pm 0.02$ & 2766.2 \\
\hline & & &
\end{tabular}

*Data obtained from APS log book.

January 1990 (Table 5). Of this, green mussels accounted for 164 tonnes $(88 \%)$, followed by barnacles $(2.7 \%)$ and siails $(2.4 \%)$.

The percentage of live mussels (Fig. 5) in the fouling debris was relatively low during the months of February $(9.3 \%)$, March $(1.2 \%)$ and April $1988(0.8 \%)$. Thereafter, the values increased to about $50 \%$ indicating large-scale removal of live mussels from the intake tunnel. However, most of these live mussels were smaller in size (1 to $3 \mathrm{~cm}$ shell length), compared to the dead and decaying ones. A similar pattern was also noticed in 1989.

The size-frequency distribution of mussels collected on the TWS during the period February 1988 to January 1990 (Fig. 6) shows that, in the initial months following highlevel chlorination, the mussels which were removed from the tunnel were comparatively larger in size, i.e. $7 \mathrm{~cm}$ or more. During the period February to April 1988, the modal size group shifted from $7-9 \mathrm{~cm}$ to $10-11 \mathrm{~cm}$ and $11-12 \mathrm{~cm}$, indicating a progressive delay in the expulsion of mussels as their size increased. However, in May 1988, young green mussels 


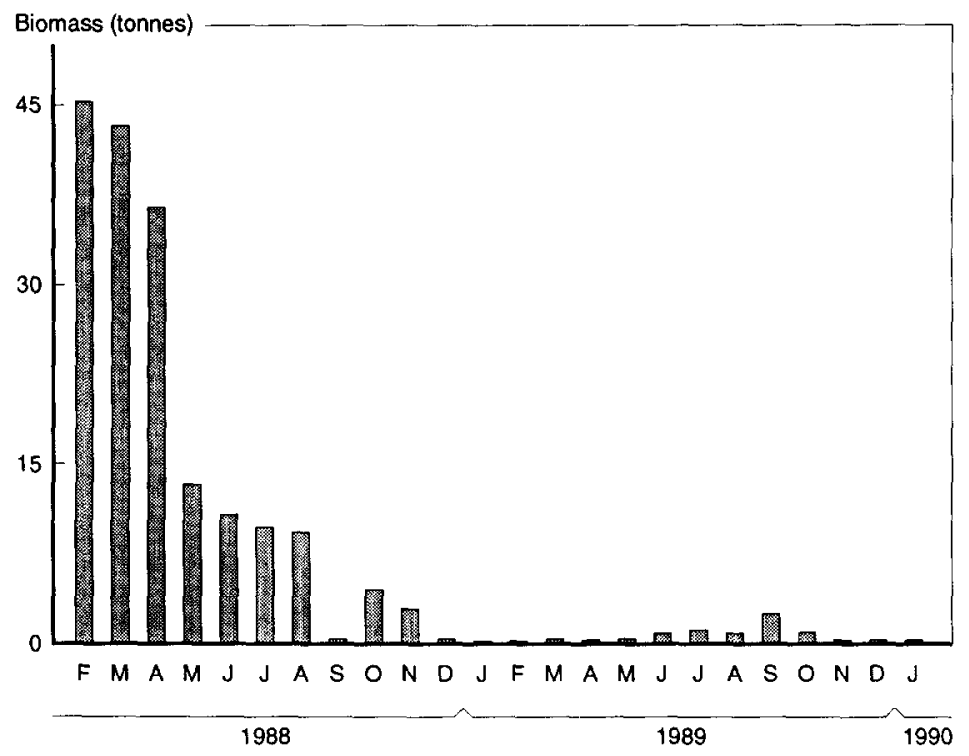

Fig. 3. Biomass of fouling debris collected on travelling water screens at forebay during February 1988 to January 1990.

$(0-3 \mathrm{~cm})$ started appearing in the collection. Their appearance is correlated with the breeding pattern of green mussels in the adjoining coastal waters (Rajagopal et al., 1991b). In the following months, the relative frequency of the smaller green mussels increased in the collection with an accompanying reduction in the number of larger mussels. An appearance of young mussels was also recorded during October 1988, May-June 1989 and October 1989, which again coincided with the observed breeding cycle of the green mussels at Kalpakkam.

\section{Growth rate}

Experiments on the growth rate of mussels in the Kalpakkam coastal waters (Fig. 7) showed that the mussels achieved a shell length of $13.1 \pm 0.5 \mathrm{~mm}$ in 30 days (30 April 1988 ) and $98.1 \pm 0.7$ in 370 days (5 April 1989).

\section{DISCUSSION}

Chlorination is commonly used to prevent settlement of fouling organisms, particularly mussels, in cooling conduits of power stations (Yamazaki, 1965; Whitehouse, 1978; Whitehouse et al., 1985). Mussel control using chlorination is well documented in the literature. Turner et al. (1948) and Anderson \& Richards (1966) observed that intermittent chlorination failed to prevent mussel settlement and growth in power plants. James (1967) also reported the ineffectiveness of the intermittent chlorination for controlling fouling in Carmarthen Bay power station. Holmes (1970a) suggested that mussels settled between intermittent chlorine injections were able to resist the subsequent exposures to chlorine. In intermittent chlorinated waters, recuperation of mussels is possible because during the 
TABLE 4

List of Fouling Organisms Observed in the Cooling System of the Madras Atomic Power Station Coelenterata

Campanulariidae

Obelia bicuspudata Clarke

Bougainvilliidae

Bimeria vestita Wright

Sertulariidae

Seriularia sp.

Sagartiidae

Sagartia sp.

Porifera

Callyspongiidae

$$
\text { Callyspongia diffusa (Ridley) }
$$

Tedaniidae

Tedania anhelans (Lieberkuhn)

Mycalidae

Mycale mytilorum Annandale

Fctoprocta

Bicellariellidae

Bugula sp.

Electridae

Electra sp.

Acanthodesia sp.

Alderina arabianensis Menon \& Nair

Membraniporidae

Membranipora sp.

Annelida

Nereidate

Perinereis sp.

Platynereis sp.

Pseudonereis $\mathrm{sp}$

Nereis sp.

Sabellidae

Dasychone sp

Sabellestarte sp.

Serpulidae

Iicopomatus sp.

Hydroides elegans (Haswell)

Serpula vermicularis Linnaeus

Arthropoda

Balanidae

Megabalanus tintinnabulum (Linnaeus)

Balanus amphitrite Darwin

Balanus amaryllus var euamaryllis Broch

Balamus reticulatus Darwin 
TABLE 4-contd.

Mollusca

Patellidae

Cellana radiata radiata Born

Trochidae

Euchelus asper Gmelin

Muricidae

Ergalatax contracta (Reeve)

Thais bufo Lamarck

Thais blanfordi (Melvill)

Thais rugosa (Born)

Thais tissoti (Petit)

Ranellidae

Lampusia pileare (Linnaeus)

Cymatium cingulatum Lamarck

Gyrineum natator (Roeding)

Architectonicidae

Architectonica perspectiva Linnaeus

Turritellidae

Turritella acutangula Linnaeus

Turritella attenuata Reeve

Nassariidae

Bullia vittata (Linnaeus)

Bullia melanoides Deshayes

Littorinidae

Littorina (Littoraria) undulata (Gray)

Littorina (Littoringosis) scabra scabra (Linnaeus)

Potamididae

Cerithidea (Cerithideopsilla) cingulata (Gmelin)

Cerithidea fluviatilis Potiez \& Michand

Telescopium telescopium (Linnaeus)

Cypraeidae

Cypraea gracilis Gaskoin

Olividae

Olivancillaria gibbosa (Born)

Dorididae

Discodoris concinna Alder \& Hancock

Dendrodorididae

Doriopsilla miniata Alder \& Hancock

Tergipedidae

Caloria militaris Alter \& Hancock

Arcidae

Anadara rhombea Born

Anadara granosa Linnaeus

Arca avellana Lamarck

Arca fusca Bruguière

Arca symmetrica Reeve

Arca gubbernaculum Reeve 
TABLE 4 - contd

Mollusca contd.

Cardiidac

Vepricardium coronatum (Spengler)

Donacidae

Donax scorlum Linnaeus

Donax cuneatus (Linnaeus)

Donax aperittus Melvill

Veneridae

Meretrix casta Chemnitz

Meretrix meretrix (Linnaeus)

Timoclea arakana (G \& H Newill)

Irus exoticus (Hanley)

Paphia textile (Gmelin)

Paphia gallus (Gmelin)

Tellinidae

Tellina angulata (Gmelin)

Carditidae

Beguina variegata (Bruguière)

Ostreidae

Crassostrea madrasensis Preston

Saccostrea cucullata Born

Pteriidae

Pinclada anomioides Reeve

Pinctada chemnitzi (Philippi)

Pinc Lada margaritifera Linnaeus

Chamidae

Chama reflexa Reeve

Chama lazarus Linnaeus

Chama fragrum Reeve

Pseudochama cristella Lamarck

Mytilidae

Perna viridis (Linnaeus)

Perna indica Kuriakose \& Nair

Modiolus striatulus Hanley

Modiolus modiohs Linnaeus

Modiolus undulata Dunker

Modiolus metcalfei Hanley

Modiolus perfragilis Dunker

Modiolus philippinartum (Hanley)

Echinodermata

Ophiuridae

Ophiothrix exigua Lyman

Chordata

Urochordata

Didemnidae

Didemnum psammathodes Sluiter Diplosoma macdonaldi Herdman Lissoclinum fragile Van Name 
TABLE 4-contd.

Chordata-contd.

Urochordata

Polyclinidae

Styelidae

Aplidium multiplicatum Sluiter

Symplegma brakenhielmi Michaelson

Symplegma viride Herdman

Styela bicolor Sluiter

Botrylloides magnicoecum Hertmeyer

Ascidiidae

Polycarpa sp.

Ascidia zara Oka

Ascidiella aspersa Müller

* Entrained organisms such as jelly fishes and fishes are not included in the list.

TABLE 5

Seasonal Variation of Relative Abundance of Different Fouling Debris on TWS in the Forebay During February 1988 to January 1990 (Wet Weight in Kilograms)

\begin{tabular}{lrrr}
\hline Months & Perna viridis & Other fouling species & Total biomass \\
\hline Feb 1988 & 44114 & 1250 & 45364 \\
Mar & 42005 & 1282 & 43287 \\
Apr & 35515 & 1088 & 36603 \\
May & 9577 & 3786 & 13363 \\
Jun & 7577 & 3162 & 10739 \\
Jul & 6256 & 3460 & 9717 \\
Aug & 7066 & 2331 & 9397 \\
Sept & 309 & 104 & 413 \\
Oct & 2165 & 2356 & 4521 \\
Nov & 1796 & 1193 & 2989 \\
Dec & 372 & 108 & 480 \\
Jan 1989 & 220 & 53 & 273 \\
Feb & 238 & 52 & 290 \\
Mar & 309 & 260 & 569 \\
Apr & 205 & 33 & 238 \\
May & 432 & 131 & 563 \\
Jun & 883 & 162 & 1045 \\
Jul & 968 & 293 & 1261 \\
Aug & 689 & 258 & 947 \\
Sept & 1923 & 594 & 2517 \\
Oct & 789 & 239 & 1028 \\
Nov & 324 & 98 & 422 \\
Dec & 290 & 65 & 355 \\
Jan 1990 & 229 & 40 & 269 \\
Total & 88.0 & 12.0 & 186648 \\
Percentage & & & 100.0 \\
\hline & & 22397 &
\end{tabular}




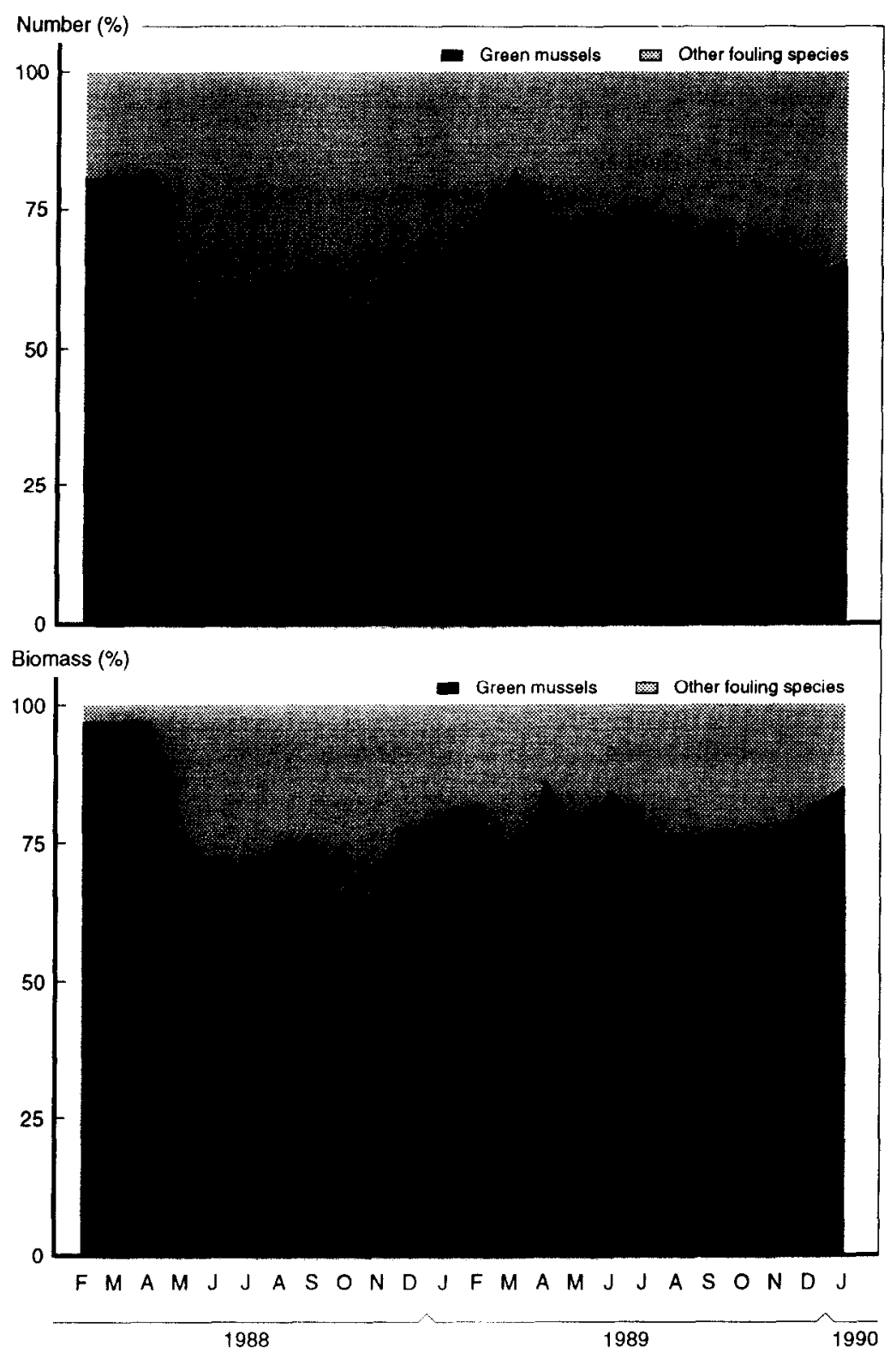

Fig. 4. Monthly variations of relative percentage (number and weight) of green mussel, Perna viridis, collected on travelling water screens at the forebay during February 1988 to January 1990.

breaks in chlorination they can actively feed and produce byssus threads (Rajagopal et al., $1991 \mathrm{~b}, 1994 \mathrm{~b}$ ). In addition, the steady flow conditions inside cooling conduits of power plants facilitates increased food availability (Jenner, 1982) and removal of metabolic wastes (Perkins, 1974; Neitzel et al., 1986). Therefore, mussels can easily compensate for any resource drain caused by short-term chlorination (Coughlan \& Whitehouse, 1981; Rajagopal et al., 1991a). The present data on head loss at forebay (Fig. 2) also clearly 


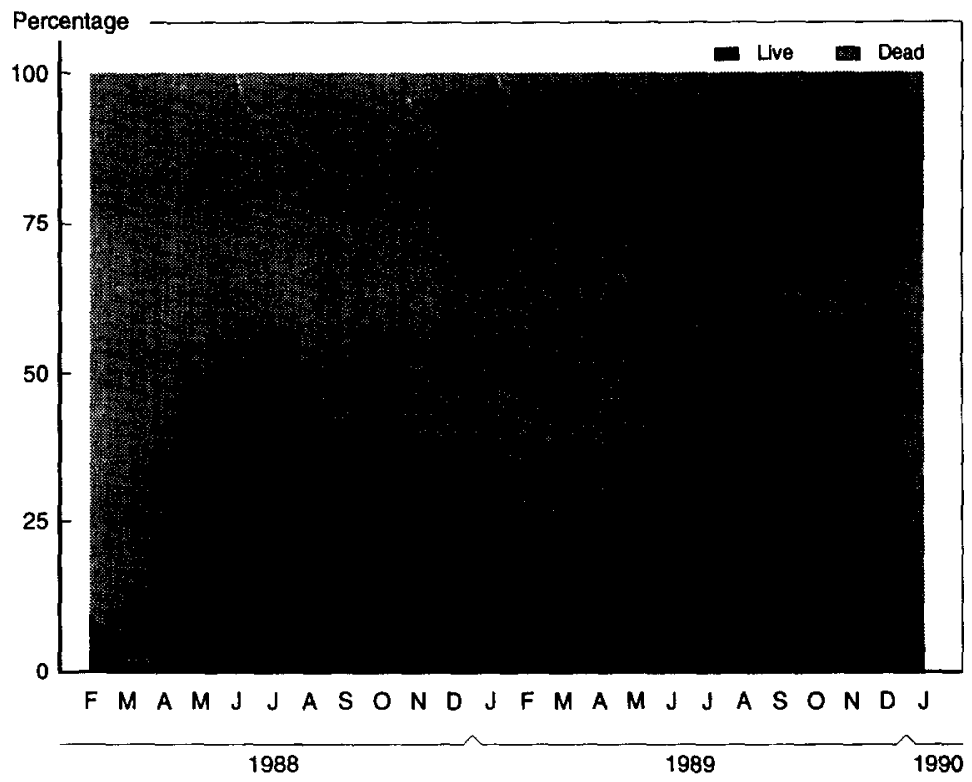

Fig. 5. Percentage composition of live and dead Perna viridis collected on travelling water screens at the forebay during February 1988 to January 1990.

indicate that the intermittent chlorination has not been effective in checking tunnel fouling at MAPS. Lewis (1985) noted that mussels treated with chlorine residuals of $4.43 \mathrm{mg} / \mathrm{litre}$ for $49 \mathrm{~h}$, were capable of making recovery within $30 \mathrm{~min}$ of exposure to ambient seawater. Jensen (1982) found that the mussels failed to recover after a $24 \mathrm{~h}$ exposure to a chlorine rcsidual of 8 to $40 \mathrm{mg} /$ litre. It is reasonable to conclude that at high chlorine residuals (eg. $40 \mathrm{mg} /$ litre), denaturation of cell membranes could lead to lethal effects, particularly in the gills (Opresko, 1980), but at low residuals only other physiological activities of mussels are affected (Khalanski \& Bordet, 1980).

Studies on the biofouling at Kalpakkam during the pre-operational phase of the power plant had predicted that barnacles, Balanus sp., would be the dominant fouling organism in the cooling system (Godwin, 1980; Karande et al., 1983). It was also pointed out that the average monthly biomass build-up at Kalpakkam coastal waters would be about $4 \mathrm{~kg} / \mathrm{m}^{2}$ with a possible yearly maximum of about $80 \mathrm{~kg} / \mathrm{m}^{2}$ (Karande et al., 1983). However the present study clearly demonstrates that tunnel fouling is actually dominated by the green mussel, P.viridis. The earlier studies were conducted by exposing test panels near the intake area and drawing conclusions based on the results thus obtained. This example points to the potential dangers involved in extrapolating test panel data to predict the extent and type of fouling in specialised environments such as cooling conduits of power stations. The present study also shows a maximum biomass value of $211 \mathrm{~kg} / \mathrm{m}^{2}$ in the forebay shaft. The comparison of the biomass values at Kalpakkam with those reported in the litcraturc shows that biomass build-up in Kalpakkam is probably one of the highest ever reported. The nearest value reported in the literature is $64 \mathrm{~kg} / \mathrm{m}^{2}$ from the water intake tunnels of a power plant at Lynn, Massachusetts (Woods Hole Oceanographic Institution, 1952). Such very high biomass accumulations at MAPS are possible because of the extremely dense settlement of bivalves, especially P.viridis. In the 


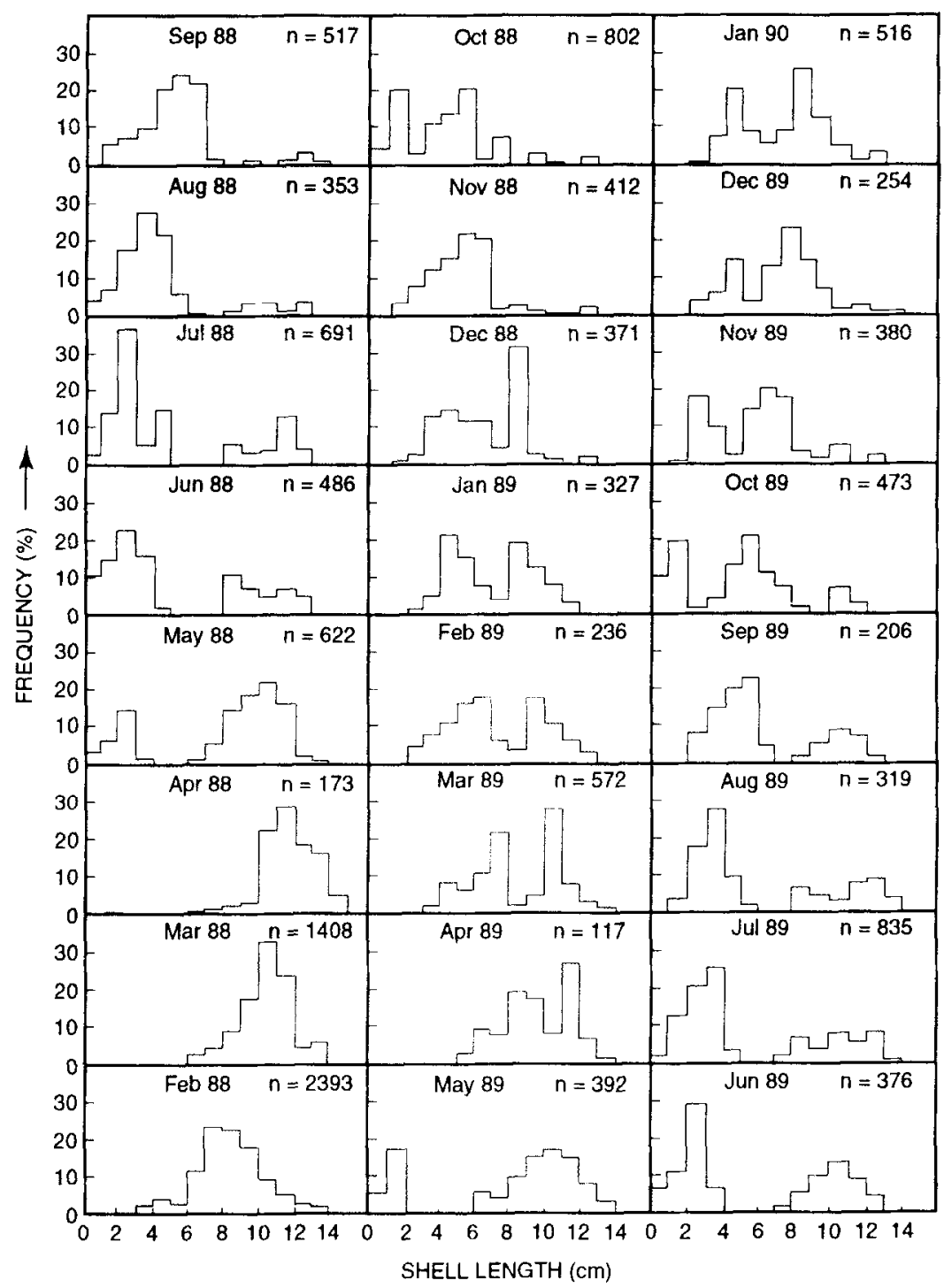

Fig. 6. Size-frequency distribution of Perna viridis collected on travelling water screens at the forebay during February 1988 to January 1990.

process of colonization of specialized environments such as seawater intake tunnels (existing flow rates, darkness and increased food availability), mussels have a competitive edge over most of the other fouling groups, and therefore mussel domination in such environments is likely at other similar localities also. In the present study, fouling debris removal data also confirmed the dominance of green mussels over the other fouling species in the cooling conduits of MAPS (Table 5).

Following high-level chlorination, fouling debris started to appear on the TWS at the forebay. During the period. February to April 1988, fouling debris dominated by P.viridis ( $>98 \%$ ) of large size ( 8 to $12 \mathrm{~cm}$ shell length) continued to get collected on the TWS. 


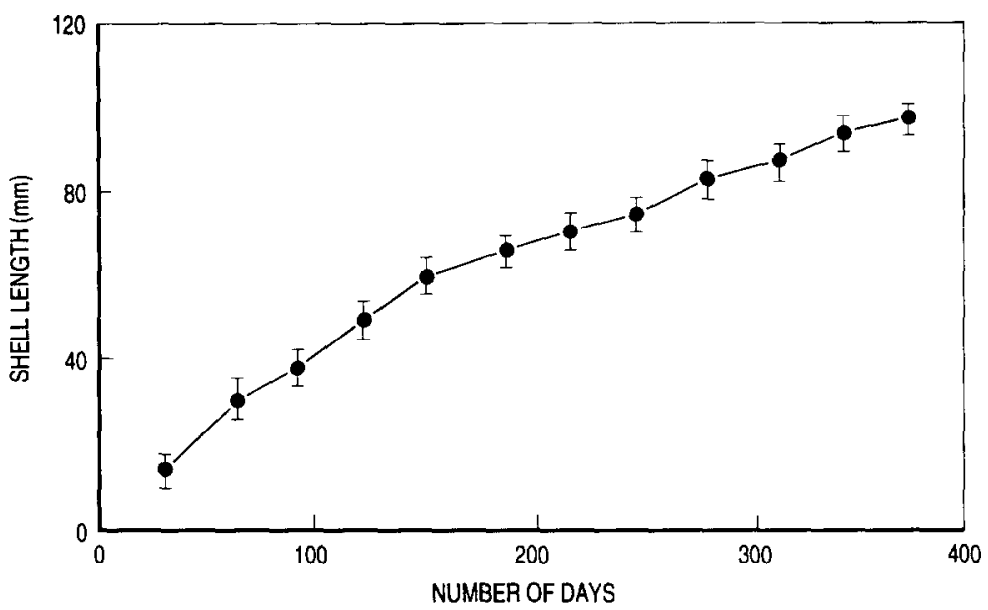

Fig. 7. Growth rate (mean $\pm \mathrm{SE}, n=30$ ) of Perna viridis in the Kalpakkam coastal waters from April 1988 to April 1989.

Most of the mussel shells contained remains of fresh tissue, suggesting a very recent demise resulting from the application of high-level chlorination. Nevertheless, mussels inside the tunnel had a layered growth pattern (as evidenced by visual observations by ROV) which precludes direct byssal contact with the primary substratum (culvert wall) for many mussels. Seed (1976) reported that mussels attached to solid substrates are relatively secure but, as the mussel hed develops, most of the mussels lose contact with the substrate and form a surface layer with feeble attachment to one another by long weak byssus threads. Thus it appears that in the early stages of fouling, mussels would have good byssal contact with the culvert wall, however, as the fouling develops and forms a thicker layer, it could become increasingly unstable and vulnerable to erosion, as suggested by Lewis (1961), Holmes (1970a) and Jenner (1983). This explains why progressive delay in the duration of expulsion of already established mussel population from the cooling conduits of MAPS. The removal of fouling debris from the intake system not only depends on the amount of chlorine injected during the chlorination regime but also on volume transport (in other words water velocity) of seawater (Fig. 8). The fate of fouling organisms (especially bivalves) within a cooling conduit is partially dependent on the flow rates within the system (Neitzel et al., 1984; Nair, 1990). Flow velocities of less than $1.2 \mathrm{~m} / \mathrm{sec}$ are known to allow mussel larvae to settle (Holmes, 1967). Once established, mussel communities are known to withstand velocities ranging from 1.5 to $2.5 \mathrm{~m} / \mathrm{sec}$ (Collins, 1964; Burton \& Liden, 1978). However, flow velocities below $0.1 \mathrm{~m} / \mathrm{sec}$ may not provide adequate food and oxygen or facilitate removal of metabolic wastes fast enough to allow dense mussel growth (Jenner, 1980; Henager et al., 1985; Venugopalan \& Nair, 1990). It is also known that if velocities are too fast to allow settlement, bivalves will not become established (Lewis, 1964). In the present study, the observed maximum $(2517 \mathrm{~kg})$ and minimum $(238 \mathrm{~kg}$ ) arrival of fouling debris on TWS for the year 1989 (Fig. 8) significantly correlated with the amount of seawater volume transported through the tunnel (Spearman rank correlation test, $p<0.001$ ). It is obvious that the shearing force created by the moving water helps removal of attached fouling biomass which has already loosened by application of chlorination. However, the data for 1988 did not show any 


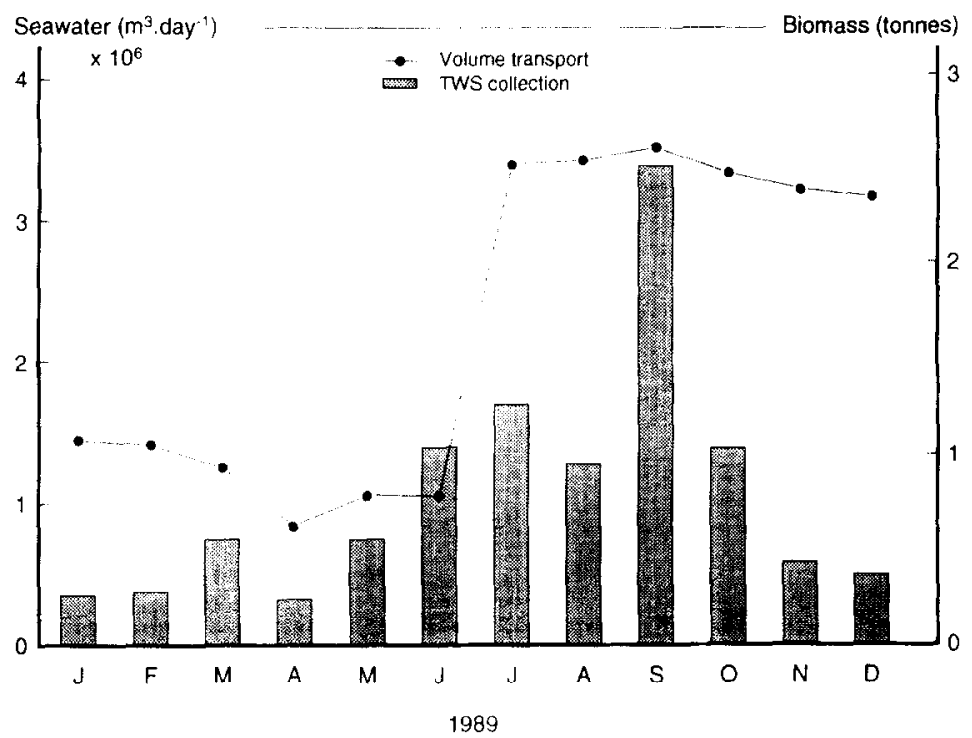

Fig. 8. Relationship between volume transport of seawater and travelling water screen debris collection at the forebay during 1989.

relation between volume transport and fouling debris on IWS. This is possibly due to the combined effects of already established fouling communities inside the MAPS submarine tunnel and adopted higher doses of chlorine residuals.

Young green mussels ( 0 to $3 \mathrm{~cm}$ shell length) started appearing on TWS during May to July 1988, October 1988, May to June 1989 and October 1989, which corresponds with the breeding season of P.viridis in Kalpakkam coastal waters (Rajagopal, 1991). Most of these young mussels $(>50 \%)$ were alive when collected on the TWS (Fig. 5), which apparently shows that continuous low-level chlorination helps to flush out juvenile mussels, before they are able to secure attachment on the tunnel walls. It is not clear whether the green mussels were actively migrating out of the tunnel as suggested by James (1967) or whether they were carried away by the flowing water as their byssal attachment was weakened because of chlorination (Holmes, 1970b). It is unlikely that continuous lowlevel chlorination completely eliminated settlement of young mussels. Size-frequency distribution of P.viridis collected on the TWS also shows a significant progressive increase in shell length, subsequent to the breeding seasons (Fig. 6). Jenner (1983) reported that there was no evidence that continuous chlorination had reduced mussel settlement in cooling conduits. He found, using side-stream monitors, that during periods of continuous chlorination at a mean residual of $0.2 \mathrm{mg} /$ litre $(0.1-0.25 \mathrm{mg} / \mathrm{litre})$, chlorine had no effect on the blue mussel, Mytilus edulis (L.), settlement at Maasvlakte power station, near Rotterdam. Khalanski \& Bordet (1980) observed that at a chlorine level between 0.2 and $0.5 \mathrm{mg} /$ litre, settlement is delayed for $30 \%$ of the mussel larvae. Thus, it seems possible that a combined effect of general weakening of the byssus attachment (Holmes, 1970a) and high flow rates inside cooling conduits, is probably responsible for such mass exodus of live mussels. It is obvious from the head loss data that MAPS intake tunnel continued to become increasingly fouled when continuous low-level chlorination was employed (Fig. 2). Given the very real difficulties of actually inspecting power station cooling water 
culverts, such head loss data is one of the few pragmatic means of monitoring the progress of fouling. Side stream fouling monitors, as described by Jenner (1985), can provide additional helpful data. In tandem, the two methods will tend to provide information on the onset, extent and character of fouling inside the cooling water culverts, together with an assessment of the control methods employed.

\section{ACKNOWLEDGEMENTS}

The authors express their sincere thanks to Dr P. N. Moorthy, Dr P. K. Mathur and Chief Superintendent of MAPS for provided facilities. Help rendered for the measurement of water levels by Shri Ramanujam and Shri Masilamani is greatly acknowledged. One of the authors (SR) is indebted to the BRNS, Bombay and CSIR, New Delhi for the award of fellowships. Grateful thanks are due to Dr S. Subba Rao, ZSI, Calcutta and Dr K. Satyanarayana Rao, CMFRI, Madras for identification of various fouling groups. The authors are thankful to Dr J. M. van Groenendael and Dr V. P. Venugopalan for critically going through the manuscript and offering valuable comments.

\section{REFERENCES}

Anderson, D. B. \& Richards, B. R. (1966). Chlorination of seawater: Effects on fouling and corrosion. Trans $A S M E, 203-8$.

Brankevich, G., Bastida, R. \& Lemmi, C. (1988). A comparative study of biofouling settlements in different sections of Necochea power plant (Quequen port, Argentina). Biofouling, 1, 113-35.

Burton, D. T. \& Liden, L. H. (1978). Biofouling control alternatives to chlorine for power plant cooling water systems: an overview. In R. L. Jolly, H. Gorchev \& D. H. Hamilton (Eds) Water Chlorination: Chemistry, Environmental Impact and Health Effects, Vol. 2. Ann Arbor Science Publishers, Ann Arbor, Michigan, pp. 717-35.

Collins, T. M. (1964). A Method for Designing Seawater Culverts Using Fluid Shear for the Prevention of Marine Fouling. Central Electricity Research Laboratories, Report No. RD/L/N 93/64, Leatherhead, Surrey, 5 pp.

Coughlan, J. \& Whitehouse, J. W. (1981). Mussel Growth and Activity in Sizewell Cooling System. Central Electricity Research Laboratories. Report No. RD/L/N 175/80, Leatherhead, Surrey, $14 \mathrm{pp}$.

Fischer, E. C., Castelli, V. J., Rodgers, S. D. \& Bleile, H. R. (1984). Fouling control technology. In J. D. Costlow \& R. C. Tipper (Eds) Marine Biodeterioration: An Interdisciplinary Study. Naval Institute Press, Annapolis, pp. 261-300.

Godwin, W. (1980). Ecology of the Coastal Fauna around Madras Atomic Power Plant, Kalpakkam. PhD thesis, University of Madras, India, $186 \mathrm{pp}$.

Graham, J. W., Monereiff, R. M. \& Bensen, P. H. (1975). Heat treatment for the control of marine fouling at coastal electric generating stations. IEEE Oceans, 926-30.

Henager, C. H., Daling, P. M. \& Johnson, K. I. (1985). Factors that may intensify the safety consequences of biofouling. In Bivalve Fouling of Nuclear Power Plant Service Water Systems. US Nuclear Regulatory Commission, Report No. NUREG/CR 4070, Washington, $15 \mathrm{pp}$.

Holmes, N. J. (1967). Mussel Settlement in the Cooling Water Intake Screens at Poole Power Stations. Central Electricity Research Laboratories, Report No. RD/L/N 137, Leatherhead, Surrey, 6 pp. 
Holmes, N. J. (1970a). The Effects of Chlorination on Mussels. Central Electricity Research Laboratories, Report No. RD/L/R 1672, Leatherhead, Surrey, 20 pp.

Holmes, N. J. (1970h). Mussel Fouling in Power Stations: The Attachment System of Mussels. Central Electricity Research Laboratories, Report No. RD/L/N 70/73, Leatherhead, Surrey, $12 \mathrm{pp}$.

James, W. G. (1967). Mussel fouling and use of exomotive chlorination. Chem. Ind., 994-6.

Jenner, H. A. (1980). The biology of the mussel Mytilus edulis in relation to fouling problems in industrial cooling water systems. La Tribune du CEBEDEAU, 33, 13-19.

Jenner, H. A. (1982). Physical methods in the control of mussel fouling in seawater cooling systems. La Tribune du CEBEDEAU, 35, 287-91.

Jenner, H. A. (1983). Control of mussel fouling in The Netherlands: experimental and existing methods. In I. A. D. Tous, M. J. Miller \& Y. G. Mussalli (Eds) Condenser Macrofouling Control Technologies: The State of the Art. Electric Power Research Institute, Hyannis, Massachusetts, pp. 12-24.

Jenner, H. A. (1985). Chlorine minimization in macrofouling control in the Netherlands. In R. L. Jolly, R. J. Bull, W. P. Davies, S. Katz, M. H. Roberts \& V. A. Jacobs (Eds) Water Chlorination: Chemistry, Environmental Impact and Health Effects, Vol. 5. Lewis Publishers Inc., Michigan, 1425 33.

Jensen, A. C. (1982). Sensitivity of Mytilus edulis (L.) to Chlorination. PhD thesis, University of Southampton, $127 \mathrm{pp}$.

Karande, A. A., Sriraman, A. K. \& Viswanathan, R. (1983). Marine Biofouling in Seawater Tunnel. Technical Report, NCML/BARC, Bombay, 24 pp.

Khalanski, M. \& Bordet, F. (1980). Effects of chlorination on marine mussels. In R. L. Jolly, W. A. Brungs \& R. B. Cumming (Eds) Water Chlorination: Chemistry, Environmental Impact and Health Effects, Vol. 3. Ann Arbor Science Publishers, Ann Arbor, Michigan, pp. 557-67.

Lewis, B. G. (1961). Biological Observations Made During Trials of Chlorination for Mussel Control at East Yelland 1959 to 1960. Central Electricity Research Laboratories, Report No. RD/L/R 1052, Leatherhead, Surrey, 8 pp.

Lewis, B. G. (1964). Water Flow and Marine Fouling in Culverts. Central Electricity Research Laboratories, Report NO. RD/L/M 60, Leatherhead, Surrey, 9 pp.

Lewis, B. G. (1985). Mussel Control and Chlorination. Central Electricity Research Laboratories, Report No. TPRD/L/2810/R85, Leatherhead, Surrey, 33 pp.

Madras Atomic Power Station Design Manual (1975). Submarine Intake Tunnel and Tunnel Dewatering. Department of Atomic Energy, Report No. 25130, Bombay, $6 \mathrm{pp}$.

Nair, K. V. K. (1990). Marine biofouling and allied problems in the condenser cooling systems of MAPS. In K. V. R. Nair \& V. P. Venugopalan (Eds) Marine Biofouling and Power Plants. Venugopalan, Bhabha Atomic Research Centre, Bombay, pp. 92-103.

Neitzel, D. A., Johnson, K. I., Page, T. L., Young, J. S. \& Daling, P. M. (1984). Correlation of bivalve biological characteristics and service water system design. In Bivalve Fouling of Nuclear Pow'er Plant Service Water Systems. US Nuclear Regulatory Commission, Report No. NUREG/CR 4070, Washington, 119 pp.

Neitzel, D. A., Johnson, K. I. \& Daling, P. M. (1986). An Evaluation of Biofouling Surveillance and Control Techniques for Use at Nuclear Power Plants. US Nuclear Regulatory Commission, Report No. NUREG/CR 4626, Washington, 37 pp.

Opresko, D. M. (1980). Review of Open Literature on Effects of Chlorine on Aquatic Organisms. Electric Power Research Institute, Report No. EPRI EA-1491, Palo Alto, California, $29 \mathrm{pp}$.

Parsons, T. R., Yoshiaki, M.\& Lalli, C. M. (1984). A Manual of Chemical and Biological Methods for Seawater Analysis. Pergamon Press, Oxford, pp. 1-173. 
Perkins, E. J. (1974). The Biology of Estuaries and Coastal Waters. Academic Press, New York, pp. 353-9.

Rajagopal, S. (1991). Biofouling Problems in the Condenser Cooling Circuit of a Coastal Power Station with Special Reference to Green Mussel, Perna viridis (L.). PhD thesis, University of Madras, India, $113 \mathrm{pp}$.

Rajagopal, S., Sasikumar, N., Azariah, J. \& Nair, K. V. K. (1991a). Some observations on biofouling in the cooling water conduits of a coastal power plant. Biofouling, 3, 311-24.

Rajagopal, S., Venugopalan, V. P., Nair, K. V. K. \& Azariah, J. (1991b). Biofouling and its control in a tropical coastal power station: A case study. Biofouling, 3, 325-38.

Rajagopal, S., Azariah, J. \& Nair, K. V. K. (1994a). Heat treatment as a fouling control method for Indian coastal power plants. In M. F. Thompson, R. Nagabhushanam R. Sarojini \& M. Fingerman (Eds) Recent Advances in Biofouling Control. Oxford and IBH Publishing Co. Pvt. Ltd, New Delhi, pp. 391-6.

Rajagopal, S., van der Velde, G. \& Jenner, H. A. (1994b). Biology and Control of Brackish Water Mussel, Mytilopsis leucophaeta in the Velsen and Hemweg Power Stations, The Netherlands. Part II. Control Measures. KEMA Environmental Services, Report No. 163871-KES/WBR 94- 3128, Arnhem, 45 pp.

Seed, R. (1976). Ecology. In B. L. Bayne (Ed) Marine Mussels: Their Ecology and Physiology. Cambridge University Press, Cambridge, pp. 13-65.

Strickland, J. D. H. \& Parsons, T. R. (1972). A Practical Handbook of Seawater Analysis. Fisheries Research Board of Canada, Ottawa, pp. 11-26.

Turner, H. J., Reynolds, D. M. \& Redfield, A. C. (1948). Chlorine and sodium pentachlorphenate as fouling preventives in seawater conduits. Ind. Eng. Chem., 40, 450-3.

Venugopalan, V.P. \& Nair, K. V. K. (1990). Effects of a biofouling community on cooling water characteristics of a coastal power plant. Indian J. Mar. Sci., 19, 294-6.

White, G. C. (1972). Handbook of Chlorination. Van Nostrand Heinhold Company, New York, pp. 228-77.

Whitehouse, J. W. (1978). Continuous low-level chlorination for marine fouling control at power stations in United Kingdom. In R. L. Jolly, H. Gorchev \& D. H. Hamilton (Eds) Water Chlorination: Environmental Impact and Health Effects, Vol. 2. Ann Arbor Science Publishers, Ann Arbor, Michigan, pp. 361-7.

Whitehouse, J. W., Khalanski, M., Saroglia, M. G. \& Jenner, H. A. (1985). The Control of Biofouling in Marine and Estuarine Power Stations. A collaborative research working group report by the Central Electricity Generating Board (England), Electricité de France (France), Ente Nazionale Energia Elettrica (Italy) and Joint Laboratories and Consulting Services of the Dutch Electricity Supply Companies (The Netherlands), $48 \mathrm{pp}$.

Woods Hole Oceanographic Institution (1952). Marine Fouling and its Prevention. United States Naval Institute, Annapolis, Maryland, 388 pp.

Yamazaki, M. (1965). Problems in using seawater for condenser cooling in thermal power stations. In E. A. Pearson (Ed) Advances in Water Pollution Research. Pergamon Press, Oxford, pp. 117-32. 